\title{
The impact of high-pressure processing treatment on microbial inactivation of seafood - a review
}

\author{
*Romulo, A. \\ Food Technology Department, Faculty of Engineering, Bina Nusantara University, Jakarta, Indonesia, \\ 11480
}

\author{
Article history: \\ Received: 13 July 2020 \\ Received in revised form: 25 \\ August 2020 \\ Accepted: 14 October 2020 \\ Available Online: 13 \\ February 2021

\section{Keywords:} \\ Seafood, \\ High Pressure Processing, \\ Pressure, \\ Foodborne Bacteria, \\ Foodborne Viruses
}

DOI:

https://doi.org/10.26656/fr.2017.5(2).352

\begin{abstract}
Seafood is categorized as high perishable food and commonly contaminated by foodborne pathogens such as bacteria and viruses. The heat processing treatment is usually applied to improve the quality and safety of seafood products and give detrimental impact to the sensory and nutritional quality. High pressure processing (HPP) has been described as an excellent alternative method to inactivate numerous bacteria and viruses in seafood products, while the organoleptic and nutritional properties could be maintained like a fresh product. HPP has been explored for a wide range of parameters operation, which is specific for each bacteria and viruses. HPP usually runs at the pressure range of 100-600 $\mathrm{MPa}$ with the holding time range of 1-60 mins. This review summarized the principle of high-pressure processing treatment and research findings, which emphasized the association between HPP treatment and food-borne pathogen reduction in seafood. The success of HPP treatment to inactivate foodborne pathogens depends on the optimization of parameters operation in order to spread this method to more applicable in seafood industries.
\end{abstract}

\section{Introduction}

Seafood is an exceptionally high perishable commodity and easily contaminated by food-borne pathogens. It is also more vulnerable to post-mortem texture deterioration than other meats. The shelf life of seafood is restricted by the growth of various strains of spoilage bacteria (Yagiz et al., 2009). There are several pieces of evidence of the occurrence of seafood-borne diseases in human when these food products are contaminated with various types of pathogens such as the bacteria from genera Vibrio, Salmonella, Listeria, Clostridium, Staphylococcus, and Yersinia (Novoslavskij et al., 2016). Classical thermal food processing is the most common technique to improve the quality of the food product. Even though high temperatures are sufficient to kill pathogen microorganisms, it could decrease the nutritional and sensory quality (W/giorgis, 2019). Therefore, the development of novel technology for food preservation without giving a detriment effect on seafood quality and safety has become the top priority to many researchers and food industries (Lou et al., 2015). Non-thermal processes such as high-pressure processing (HPP), pulse electric field (PEF), high pressure homogenization, $\mathrm{CO}_{2}$ processing, and membrane processing, have been acknowledged as green technologies and as sustainable alternatives to conventional food processing (Picart-Palmade et al., 2019).

HPP is an alternative non-thermal technology that has gained attention by many researchers and food industries in recent years due to the capability to produce high-quality foods, maintain the characteristics of fresh products, and prolong the food's shelf life (Queiroz et al., 2010). HPP has been described to give a better effect on microbial quality and physicochemical properties than another non-thermal treatment such as PEF (Roobab et al., 2018). HPP is considered as cold processing technology because the process runs at ambient temperature. It usually involves the product that is sealed in a package, introduced into the chamber, and subjected to a high level of isostatic pressure. This process can preserve the food without losing the organoleptic and nutritional quality, while the unwanted microorganisms are killed (W/giorgis, 2019). The HPP treatment has been applied to many seafood products and showed some promising results due to the ability to inactivate the foodborne pathogens. It also enables the seafood products to retain its flavors, maintain organoleptic and nutritional 
qualities, thus allowing the extension of the product's shelf life and stability (Elamin et al., 2015). This review summarized the principle of high-pressure processing treatment and research findings, which emphasized the association between HPP treatment and food-borne pathogen reduction in seafood products.

\section{Principle of high-pressure processing (HPP)}

The running principles of high-pressure processing are based on the isostatic rule applied to the food with various sizes or shapes. Under the isostatic condition, the pressure is transmitted uniformly throughout a sample with direct contact with the pressurized medium (Rastogi et al., 2007). Generally, HPP is mainly employed in a batch process where the aseptically prepackaged food products are treated in a chamber surrounded by water or another pressure-transmitting fluid. However, it could be modified into a semicontinuous process for liquid foods with different rheological properties that have the flexibility of receiving the HPP treatment (Ting and Marshal, 2002). The packaging uses in HPP must have the flexibility to transmit pressure, high barrier properties, not rigid properties (e.g., plastic), and without the headspace air. The HPP machine is typically built with high-quality steel alloys with excellent strength, toughness, and able to endure the fracture and corrosion (Balasubramaniam et al., 2015).

The HPP system usually includes a pressure vessel, vessel closures, a tool for holding the closure in place while the machine is working (e.g., yoke), intensifier pump for generating pressure; a processing control of pressure and temperature instrumentation, and a producthandling system for transferring and withdrawing the product from the chamber. The process of HPP treatment is begun with the loading of the product into a highpressure chamber. Then, the chamber will be filled with the pressurized transmitting fluid, either by decreasing the volume of the pressure chamber by a piston or by increasing the pressure by a pump. Several types of fluids are used in the instrument, such as water, ethanol, glycol, castor oil, and silicon benzoate. Water is the most commonly used medium as it could be compressed up to $15 \%$ volume at the pressure beyond $600 \mathrm{MPa}$. When the target pressure is achieved, the food product is held at the target pressure for a period of time (holding time). After receiving the treatment, the pressure on the system is decreased, and the sample is taken out from the chamber (Woldemariam and Emire, 2019).

\section{Effect of high-pressure processing (HPP) against food-borne bacteria}

The application of HPP has been regarded as an effective preservation method to diminish the microorganisms. Besides the isostatic pressure, the effect of HPP on the microorganism could be explained, according to Le Chatelier's principle. The HPP disturbs the equilibrium in the food system and stimulates the chemical reactivity, change in molecular configuration, chemical reaction, phase transition, and volume decrease (W/giorgis, 2019). When HPP is applied to the seafood product, the changes occur to some microorganisms, especially to the number of microorganisms, as described in Table 1.

Based on the summarized data, the HPP treatment is proven useful to inactivate pathogenic microorganisms. Generally, the HPP treatment inactivates the microorganisms through several mechanisms, mainly due to the cell wall's changes, cell membranes, and alteration of protein-mediated cellular function. Figure 1 shows the schematic mechanism of bacterial inactivation. The pressure treatment causes damage to the cell membranes. This damage disturbs the cell permeability and causing osmotic responsiveness. It also disables the ability to maintain intracellular $\mathrm{pH}$. Several pressure powers have been observed to have a significant effect on the membrane cell. The pressure up to $100 \mathrm{MPa}$ causes the conformational change in the membrane protein and loss the membrane-bound enzyme's function. At pressures of 100-220 MPa, dissociation and conformational changes in the protein subunits occur. The membrane structure is destroyed and fragmented at the pressure of $220 \mathrm{MPa}$ or higher due to protein unfolding and separation of interface protein. These lead to the leakage of intracellular material and the destruction of the nucleus (Woldemariam and Emire, 2019).

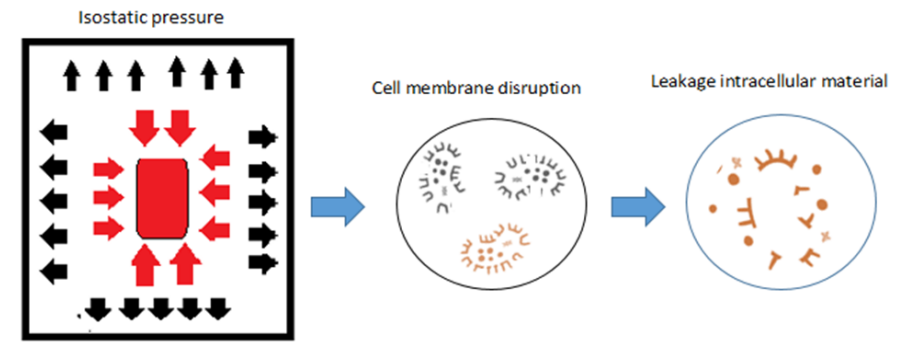

Figure 1. Bacterial inactivation by HPP

It should be considered that HPP parameters are specific for the microorganism. As shown in Table 1, different species of pathogens have different pressure resistance. Besides, the type of bacteria (Gram-positive or Gram-negative), the growth phase of the microorganism (stationary phase and exponential phase), 
Table 1. HPP effect on the inactivation of foodborne bacteria

\begin{tabular}{|c|c|c|c|c|c|}
\hline Product & Pressure & Time & Target & Microbial Reduction & Reference \\
\hline $\begin{array}{l}\text { Mackerel } \\
\text { (Scomber scombrus) }\end{array}$ & $300 \mathrm{MPa}$ & 5 mins & Mesophilic bacteria & $1.7 \log \mathrm{CFU} / \mathrm{g}$ & $\begin{array}{l}\text { Cropotova et al. } \\
(2020)\end{array}$ \\
\hline $\begin{array}{l}\text { Haddock (Melanogrammus } \\
\text { aeglefinus) }\end{array}$ & & & & $>1.0 \log \mathrm{CFU} / \mathrm{g}$ & \\
\hline $\begin{array}{l}\text { Mackerel } \\
\text { (Scomber scombrus) }\end{array}$ & $\begin{array}{l}250-400 \\
\mathrm{MPa}\end{array}$ & $\begin{array}{l}0-60 \\
\operatorname{mins}\end{array}$ & $\begin{array}{l}\begin{array}{l}\text { Escherichia coli } \\
(\mathrm{O} 157: \mathrm{H} 7)\end{array} \\
\text { Listeria } \\
\text { monocytogenes } \\
\text { (Scott A) }\end{array}$ & $\begin{array}{l}2-4 \log \mathrm{CFU} / \mathrm{ml} \\
1-3.5 \log \mathrm{CFU} / \mathrm{ml}\end{array}$ & $\begin{array}{l}\text { Ramaswamy et } \\
\text { al. (2008) }\end{array}$ \\
\hline $\begin{array}{l}\text { Albacore Tuna (Thunnus } \\
\text { alalunga) minced }\end{array}$ & $\begin{array}{l}275-310 \\
\mathrm{MPa}\end{array}$ & $2-6$ mins & $\begin{array}{l}\text { Mesophilic } \\
\text { microorganism }\end{array}$ & $<2 \log \mathrm{CFU} / \mathrm{ml}$ & $\begin{array}{l}\text { Ramirez-Suarez } \\
\text { and Morrissey } \\
(2006)\end{array}$ \\
\hline $\begin{array}{l}\text { Black Tiger Shrimp (Penaeus } \\
\text { monodon) }\end{array}$ & $\begin{array}{l}100-435 \\
\mathrm{MPa}\end{array}$ & 5 mins & $\begin{array}{l}\text { Total } \\
\text { Microorganism } \\
\text { Escherichia coli } \\
\text { Staphylococcus } \\
\text { aureus }\end{array}$ & $\begin{array}{c}0.1-1.2 \log \text { CFU/g } \\
0.4-1.5 \log \text { CFU/g } \\
0.3-1.0 \log \text { CFU/g }\end{array}$ & $\begin{array}{l}\text { Kaur et al. } \\
(2013)\end{array}$ \\
\hline $\begin{array}{l}\text { Pacific oysters (Crassostrea } \\
\text { gigas) }\end{array}$ & $\begin{array}{l}207-310 \\
\mathrm{MPa}\end{array}$ & $0-2$ mins & Coliform & $2-3 \log$ CFU/g & He et al. (2002) \\
\hline Oysters & $\begin{array}{l}200-300 \\
\mathrm{MPa}\end{array}$ & $\begin{array}{l}5-10 \\
\operatorname{mins}\end{array}$ & $\begin{array}{l}\text { Vibrio } \\
\text { parahaemolyticus }\end{array}$ & $>7.4 \log \mathrm{CFU} / \mathrm{g}$ & $\begin{array}{l}\text { Phuvasate and } \\
\mathrm{Su}(2015)\end{array}$ \\
\hline $\begin{array}{l}\text { Oysters } \\
\text { (Crassostrea virginica) }\end{array}$ & $\begin{array}{l}150-300 \\
\mathrm{MPa}\end{array}$ & $\begin{array}{l}1-20 \\
\operatorname{mins}\end{array}$ & Vibrio vulnificus & $>5.0 \log \mathrm{CFU} / \mathrm{ml}$ & $\begin{array}{l}\text { Kural et al. } \\
(2008)\end{array}$ \\
\hline Atlantic salmon (Salmo salar) & $0-300 \mathrm{MPa}$ & 15 mins & Total Aerobic & $2.0-3.0 \log \mathrm{CFU} / \mathrm{g}$ & $\begin{array}{l}\text { Yagiz et al. } \\
(2009)\end{array}$ \\
\hline Octopus (Octopus vulgaris) & $\begin{array}{l}150-600 \\
\mathrm{MPa}\end{array}$ & 6 mins & $\begin{array}{l}\text { Psychrotropic } \\
\text { bacteria }\end{array}$ & $0.1-2.8 \log \mathrm{CFU} / \mathrm{ml}$ & $\begin{array}{l}\text { Hsu et al. } \\
(2014)\end{array}$ \\
\hline Mussels (Mytilus edulis) & $\begin{array}{l}300-600 \\
\mathrm{MPa}\end{array}$ & 2 mins & $\begin{array}{l}\text { Total Aerobic } \\
\text { Pseudomonads } \\
\text { Coliform } \\
\end{array}$ & $\begin{array}{l}<1.0 \log \mathrm{CFU} / \mathrm{g} \\
3.0 \log \mathrm{CFU} / \mathrm{g} \\
2.0 \log \mathrm{CFU} / \mathrm{g}\end{array}$ & \\
\hline $\begin{array}{l}\text { Dublin bay prawns (Nephrops } \\
\text { norvegicus) }\end{array}$ & $\begin{array}{l}300-600 \\
\mathrm{MPa}\end{array}$ & 2 mins & $\begin{array}{l}\text { Total Aerobic } \\
\text { Pseudomonads } \\
\text { Coliform }\end{array}$ & $\begin{array}{l}\frac{1.0 \log \text { CFU/g }}{3.0 \log \text { CFU } / g} \\
2.0 \log \text { CFU } / g\end{array}$ & Linton et al. \\
\hline Scallops (Pecten maximus) & $\begin{array}{l}300-600 \\
\mathrm{MPa}\end{array}$ & 2 mins & $\begin{array}{l}\text { Total Aerobic } \\
\text { Pseudomonads } \\
\text { Coliform } \\
\end{array}$ & $\begin{array}{l}\frac{1.0-1.5 \log \mathrm{CFU} / \mathrm{g}}{1.0-2.0 \log \mathrm{CFU} / \mathrm{g}} \\
<1.0 \log \mathrm{CFU} / \mathrm{g}\end{array}$ & $(2003)$ \\
\hline Oysters (Crassostroea gigas) & $\begin{array}{l}300-600 \\
\mathrm{MPa}\end{array}$ & 2 mins & $\begin{array}{l}\text { Total Aerobic } \\
\text { Pseudomonads } \\
\text { Coliform }\end{array}$ & $\begin{array}{l}1.0 \log \mathrm{CFU} / \mathrm{g} \\
2.0 \log \mathrm{CFU} / \mathrm{g} \\
-\end{array}$ & \\
\hline Squid (Todarodes pacificus) & $\begin{array}{l}200-400 \\
\mathrm{MPa}\end{array}$ & $1-2$ mins & $\begin{array}{l}\text { Psychrotrophic } \\
\text { bacteria }\end{array}$ & $0.5-6.0 \log \mathrm{CFU} / \mathrm{g}$ & $\begin{array}{l}\text { Gou et al. } \\
(2010)\end{array}$ \\
\hline Chilled cold-smoked salmon & $\begin{array}{l}0.1-250 \\
\mathrm{MPa}\end{array}$ & 20 mins & $\begin{array}{l}\text { Listeria } \\
\text { monocytogenes }\end{array}$ & $<0.5 \log \mathrm{CFU} / \mathrm{g}$ & $\begin{array}{l}\text { Lakshmanan } \\
\text { and Dalgaard } \\
(2004)\end{array}$ \\
\hline
\end{tabular}

and the holding time in the machine determine the effectiveness of HPP to reduce and kill the bacteria (Bello et al., 2014; Daher et al., 2017). Although the pressure at a certain level able to destruct most of the vegetative cells, the bacterial spores are incredibly resistant up to $1000 \mathrm{MPa}$ pressure (Woldemariam and Emire, 2019). It exhibits a particular challenge for using the HPP technology in food processing of seafood due to the safety concern regarding the use of very high pressure. Some research suggests that applied pressure at more than $1000 \mathrm{MPa}$ and longer exposure time are the minimum requirements to inactivate the spores. However, the combination with temperature or two-time exposure treatment enhances the HPP ability to inactivate and destruct the spores (Daher et al., 2017).

\section{Effect of high-pressure processing (HPP) against food-borne viruses}

A foodborne virus is defined as any virus that may be transmitted by food and is able to cause illness via the fecal-oral route. Enteric viruses such as human norovirus (NoV), rotaviruses (RVs), hepatitis A virus (HAV), and human sapovirus are the most prevalent viral pathogens associated with foodborne outbreaks (Araud et al., 2015). Foodborne viruses are obligate intracellular parasites. They can only replicate themselves inside the host's living cells (Lou et al., 2015). Based on this nature, the viruses cannot multiply in dead hosts, cannot 
amplify during the processing, storage, and distribution of food products, and are not responsible for the food spoilage. However, the contamination through the fecaloral route can passively transfer the virus to humans and induce the maladies. This contamination route has become a significant cause of viral contamination in seafood products. Generally, the transmission of the viruses to the seafood is initiated through water pollution (sewage and dirty water) or post-processing contamination (Bosch et al., 2008).

HPP has been recognized as a practical approach to eliminate the virus contamination on seafood products without altering the freshness and organoleptic quality. Table 2 summarized the application of HPP to reduce or eliminate the virus in seafood products. From the summarized data, it can be known that HPP is sufficient to inactivate the virus. Generally, the inactivation of the virus by HPP treatment is induced by the damage to the viral genetic material, structural and functional changes of the protein capsid, and disruption of the lipid envelope that surrounds the capsid (Lou et al., 2015). The effectiveness of the treatment is influenced by many variables, such as processing parameters (pressure, temperature, and holding time) and non-processing parameters (virus structure, water activity (aw), $\mathrm{pH}$, and food matrices) (Lou et al., 2015). The data in Table 2 showed that viruses have a distinct treatment condition.
The differences in virus properties (enveloped and nonenveloped) make the parameters treatment varies among the viruses. The enveloped virus such as norovirus has shown their ability to withstand the high pressure due to the lipid surrounding the capsid (Lou et al., 2015; Tang et al., 2010). The primary and secondary structures of capsid protein able to remain intact after HPP treatment, where the viral genomic RNA remains undamaged (Lou et al., 2011).

Comprehensive studies about the effect of the variables on virus inactivation by HPP, primarily related to the formulation of products and optimization of processing and non-processing parameters, would be beneficial to maintain the organoleptic and nutritional quality of seafood product without neglecting the food safety. The optimization with a focus on the use of lower pressure to obtain the target quality and safety in the product is needed. The use of higher pressure has some limitations due to the concern of maximum allowable pressure levels and operation cost, which has a direct relationship with the higher pressure (Farkas and Hoover, 2000). Moreover, the initial investment cost for HPP equipment is quite high, limiting the application of HPP for small-scale industries. The increased demand for seafood products that are fresh, safe, and nutritious will play as a significant factor that triggers advanced processing innovation in high-pressure treatment, thus

Table 2. HPP effect on the inactivation of foodborne viruses.

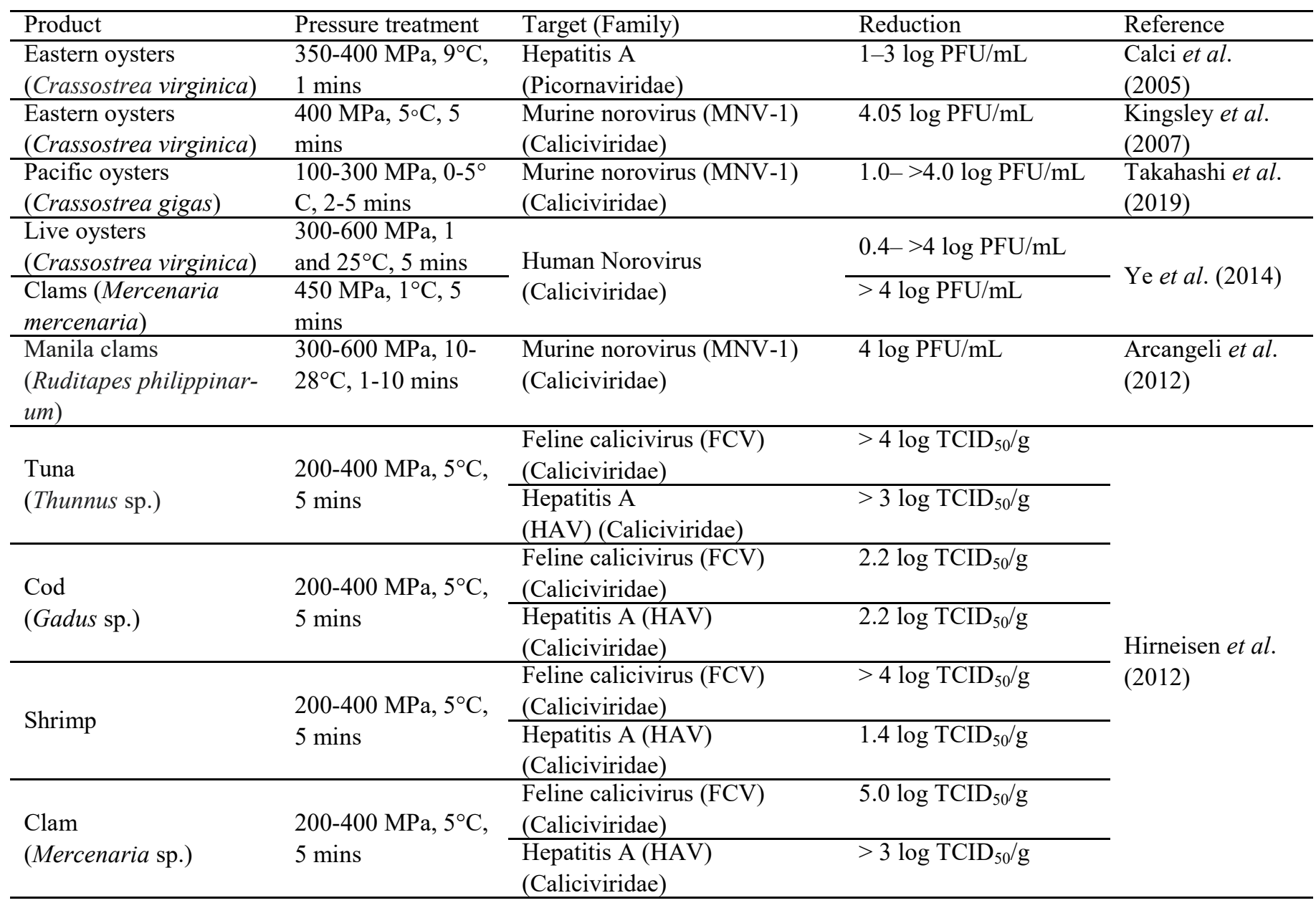


reducing the investment and operating costs of HPP (Lou et al., 2015).

\section{Conclusion}

The increase of consumer demand for fresh product, acceptable organoleptic properties, and maintain nutritional quality and safety, and longer shelf life, facilitates the use of high-pressure processing (HPP) in seafood products. HPP treatment is considered as nonthermal technology that provides a unique opportunity to food processors for inactivating various pathogenic bacteria and viruses without giving a detrimental impact to the product attribute. The inactivation of bacteria and viruses is influenced by processing and non-processing parameters. Thus, the optimization of these parameters becomes crucial for the success of the HPP treatment. Through the optimization, it is expected to be able to reduce the initial equipment and operational cost of HPP, so that the HPP is more applicable to seafood industries.

\section{Conflict of interest}

The author declares no conflict of interest.

\section{Acknowledgments}

The Author acknowledge Bina Nusantara University Research and Technology Transfer Office (RTTO) for providing financial assistantship for the publication (Internal Grant 2020).

\section{References}

Araud, E., DiCaprio, E., Yang, Z., Li, X., Lou, F., Hughes, J.H., Chen, H. and Li, J. (2015). Highpressure inactivation of rotaviruses: role of treatment temperature and strain diversity in virus inactivation. Applied and Environmental Microbiology, 81(19), 6669-6678. https://doi.org/10.1128/AEM.01853-15

Arcangeli, G., Terregino, C., De Benedictis, P., Zecchin, B., Manfrin, A., Rossetti, E., Magnabosco, C., Mancin, M. and Brutti, A. (2012). Effect of high hydrostatic pressure on murine norovirus in Manila clams. Letters in Applied Microbiology, 54(4), 325$329 . \quad$ https://doi.org/10.1111/j.1472765X.2012.03211.X

Balasubramaniam, V.M., Martínez-Monteagudo, S.I. and Gupta, R. (2015). Principles and application of high pressure-based technologies in the food industry. Annual Review of Food Science and Technology, 6 (1), 435-462. https://doi.org/10.1146/annurev-food022814-015539

Bello, E.F.T., Martínez G.G., Ceberio B.F.K., Rodrigo, D. and López, A.M. (2014). High pressure treatment in foods. Foods, 3, 476. https://10.3390/ foods 3030476

Bosch, A., Pintó, R.M., Lees, D.H., von Bonsdorff, C.H., Croci, L., De Medici, D. and Le Guyader, F.S. (2008). Detecting virus contamination in seafood. In Borrresen, T. (Ed.) Improving Seafood Products for the Consumer, p. 194-211. USA: Woodhead Publishing. doi.org/10.1533/9781845694586.3.194

https://

Calci, K.R., Meade, G.K., Tezloff, R.C. and Kingsley, D.H. (2005). High-pressure inactivation of hepatitis a virus within oysters. Applied and Environmental Microbiology, 71(1), 339-343. https:// doi.org/10.1128/AEM.71.1.339-343.2005

Cropotova, J., Mozuraityte, R., Standal, I.B., Ojha, S., Rustad, T. and Tiwari, B. (2020). Influence of highpressure processing on quality attributes of haddock and mackerel minces during frozen storage, and fishcakes prepared thereof. Innovative Food Science and Emerging Technologies, 59, 102236. https:// doi.org/10.1016/j.ifset.2019.102236

Daher, D., Le Gourrierec, S. and Pérez-Lamela, C. (2017). Effect of high-pressure processing on the microbial inactivation in fruit preparations and other vegetable-based beverages. Agriculture, 7(9), 72. https://doi.org/10.3390/agriculture7090072

Elamin, W.M., Endan, J., Yusof, Y.A., Shamsudin, R. and Ahmedov, A. (2015). Effect of high-pressure processing on sensory and physical attributes of Malaysian shrimps and mud crabs. American Scientific Research Journal for Engineering, Technology, and Sciences (ASRJETS), 14(2), 91-96.

Gou, J., Xu, H., Choi, G.P., Lee, H.Y.and Ahn, J. (2010). Application of high-pressure processing for extending the shelf-life of sliced raw squid. Food Science and Biotechnology, 19(4), 923-927. https:// doi.org/10.1007/s10068-010-0130-y

He, H., Adams, R.M., Farkas, D.F. and Morrissey, M.T. (2002). Use of high-pressure processing for oyster shucking and shelf-life extension. Journal of Food Science, 67(2), 640-645. https://doi.org/10.1111/ j.1365-2621.2002.tb10652.x

Hirneisen, K.A., Hoover, D.G., Hicks, D.T., Pivarnik, L.F. and Kniel, K.E. (2012). Pressure inactivation of enteric viruses in a seafood salad-like product. Journal of Aquatic Food Product Technology, 21(5), 455-467.

https:// doi.org/10.1080/10498850.2011.609636

Hsu, C.-P., Huang, H.W. and Wang, C.Y. (2014). Effects of high-pressure processing on the quality of chopped raw octopus. LWT - Food Science and Technology, 56(2), 303-308. https://doi.org/10.1016/ 
j.lwt.2013.11.025

Lakshmanan, R. and Dalgaard, P. (2004). Effects of high -pressure processing on Listeria monocytogenes, spoilage microflora and multiple compound quality indices in chilled cold-smoked salmon. Journal of Applied Microbiology, 96(2), 398-408. https:// doi.org/10.1046/j.1365-2672.2004.02164.x

Linton, M., Clements, J.M.J.M. and Patterson, M.F. (2003). Changes in the microbiological quality of shellfish, brought about by treatment with high hydrostatic pressure. International Journal of Food Science and Technology, 38(6), 713-727. https:// doi.org/10.1046/j.1365-2621.2003.00724.x

Lou, F., Neetoo, H., Chen, H. and Li, J. (2015). High hydrostatic pressure processing: a promising nonthermal technology to inactivate viruses in highrisk foods. Annual Review of Food Science and Technology, 6(1), 389-409. https://doi.org/10.1146/ annurev-food-072514-104609

Lou, F., Neetoo, H., Chen, H. and Li, J. (2011). Inactivation of a human norovirus surrogate by highpressure processing: effectiveness, mechanism, and potential application in the fresh produce industry. Applied Environmental Microbiology, 77(5), 18621871. https://doi.org/10.1128/AEM.01918-10

Kaur, B.P., Kaushik, N., Rao, P.S. and Chauhan, O.P. (2013). Effect of high-pressure processing on physical, biochemical, and microbiological characteristics of black tiger shrimp (Penaeus monodon). Food and Bioprocess Technology, 6(6), 1390-1400. https://doi.org/10.1007/s11947-0120870-1

Kingsley, D.H., Holliman, D.R., Calci, K.R., Chen, H. and Flick, G.J. (2007). Inactivation of a norovirus by high-pressure processing. Applied and Environmental Microbiology, 73(2), 581-585. https://doi.org/10.1128/AEM.02117-06

Kural, A.G., Shearer, A.E.H., Kingsley, D.H. and Chen, H. (2008). Conditions for high pressure inactivation of Vibrio parahaemolyticus in oysters. International Journal of Food Microbiology, 127(1), 1-5. https:// doi.org/10.1016/j.jiffoodmicro.2008.05.003

Novoslavskij, A., Terentjeva, M., Eizenberga, I., Valciņa, O., Bartkevičs, V. and Bērziňš, A. (2016). Major foodborne pathogens in fish and fish products: a review. Annals of Microbiology, 66(1), 1-15. https://doi.org/10.1007/s13213-015-1102-5

Picart-Palmade L., Cunault, C., Chevalier-Lucia, D., Belleville, M.P. and Marchesseau, S. (2019). Potentialities and limits of some non-thermal technologies to improve sustainability of food processing. Frontier in Nutrition, 5, e00130. https:// doi.org/10.3389/fnut.2018.00130

Phuvasate, S. and Su, Y.-C. (2015). Efficacy of lowtemperature high hydrostatic pressure processing in inactivating Vibrio parahaemolyticus in culture suspension and oyster homogenate. International Journal of Food Microbiology, 196, 11-15. https:// doi.org/10.1016/j.ijfoodmicro.2014.11.018

Queiroz, C., Moreira, C.F.F., Lavinas, F.C., Lopes, M.L.M., Fialho, E., and Valente-Mesquita, V.L. (2010). Effect of high hydrostatic pressure on phenolic compounds, ascorbic acid and antioxidant activity in cashew apple juice. High Pressure Research, 30(4), 507-513. https:// doi.org/10.1080/08957959.2010.530598

Ramaswamy, H.S., Zaman, S.U. and Smith, J.P. (2008). High pressure destruction kinetics of Escherichia coli $(\mathrm{O} 157: \mathrm{H7})$ and Listeria monocytogenes (Scott A) in a fish slurry. Journal of Food Engineering, 87 (1), 99-106. https://doi.org/10.1016/ j.jfoodeng.2007.11.017

Ramirez-Suarez, J.C. and Morrissey, M.T. (2006). Effect of high-pressure processing (HPP) on shelf life of albacore tuna (Thunnus alalunga) minced muscle. Innovative Food Science and Emerging Technologies, 7(1), 19-27. https://doi.org/10.1016/ j.ifset.2005.08.004

Rastogi, N.K., Raghavarao, K.S.M.S., Balasubramaniam, V.M., Niranjan, K. and Knorr, D. (2007). Opportunities and challenges in high pressure processing of foods. Critical Reviews in Food Science and Nutrition, 47(1), 69-112. https:// doi.org/10.1080/10408390600626420

Roobab, U., Aadil, R.M., Madni, G.M. and Bekhit, A.ED. (2018). The impact of nonthermal technologies on the microbiological quality of juices: a review. Comprehensive Reviews in Food Science and Food Safety, 17(2), 437-457. https://doi.org/10.1111/1541 $-4337.12336$

Takahashi, M., Okakura, Y., Takahashi, H., Yamane, H., Akashige, S., Kuda, T. and Kimura, B. (2019). Evaluation of inactivation of murine norovirus in inoculated shell oysters by high hydrostatic pressure treatment. Journal of Food Protection, 82(12), 2169 -2173. https://doi.org/10.4315/0362-028X.JFP-19186

Tang, Q., Li, D., Xu, J., Wang, J., Zhao, Y., Li, Z. and Xue, C. (2010). Mechanism of inactivation of murine norovirus-1 by high pressure processing. International Journal of Food Microbiology, 137(23), 186-189. https://doi.org/10.1016/ j.ijfoodmicro.2009.10.033

W/giorgis, G.A. (2019). Review on high-pressure 
processing of foods. Cogent Food and Agriculture, 5

(1), $1568725 . \quad$ https:// doi.org/10.1080/23311932.2019.1568725

Woldemariam, H.W. and Emire, S.A. (2019). High pressure processing of foods for microbial and mycotoxins control: current trends and future prospects. Cogent Food and Agriculture, 5(1), 1622184. https:// doi.org/10.1080/23311932.2019.1622184

Yagiz, Y., Kristinsson, H.G., Balaban, M.O. and Marshall, M.R. (2007). Effect of high-pressure treatment on the quality of rainbow trout (Oncorhynchus mykiss) and mahi mahi (Coryphaena hippurus). Journal of Food Science, 72(9), C509515. https://doi.org/10.1111/j.17503841.2007.00560.x

Yagiz, Y., Kristinsson, H.G., Balaban, M.O., Welt, B.A., Ralat, M. and Marshall, M.R. (2009). Effect of highpressure processing and cooking treatment on the quality of Atlantic salmon. Food Chemistry, 116(4), 828-835. https://doi.org/10.1016/ j.foodchem.2009.03.029

Ye, M., Li, X., Kingsley, D. H., Jiang, X. and Chen, H. (2014). Inactivation of human norovirus in contaminated oysters and clams by high hydrostatic pressure. Applied and Environmental Microbiology, 80(7), 2248-2253. https://doi.org/10.1128/ AEM.04260-13 